\title{
PTPN11-Associated Mutations in the Heart: Has LEOPARD Changed Its RASpots?
}

\section{Citation}

Lauriol, Jessica, and Maria I. Kontaridis. 2011. “PTPN11-Associated Mutations in the Heart: Has LEOPARD Changed Its RASpots?" Trends in Cardiovascular Medicine 21 (4) (May): 97-104. doi:10.1016/j.tcm.2012.03.006.

\section{Published Version}

doi:10.1016/j.tcm.2012.03.006

\section{Permanent link}

http://nrs.harvard.edu/urn-3:HUL.InstRepos:30203521

\section{Terms of Use}

This article was downloaded from Harvard University's DASH repository, and is made available under the terms and conditions applicable to Other Posted Material, as set forth at http:// nrs.harvard.edu/urn-3:HUL.InstRepos:dash.current.terms-of-use\#LAA

\section{Share Your Story}

The Harvard community has made this article openly available.

Please share how this access benefits you. Submit a story.

\section{Accessibility}




\title{
PTPN11-Associated Mutations in the Heart: Has LEOPARD changed its RASpots?
}

\author{
Jessica Lauriol ${ }^{1}$ and Maria I. Kontaridis ${ }^{1,2}$ \\ ${ }^{1}$ Department of Medicine, Division of Cardiology, Beth Israel Deaconess Medical Center, Boston, \\ MA \\ ${ }^{2}$ Department of Biological Chemistry and Molecular Pharmacology, Harvard Medical School, \\ Boston, MA
}

\begin{abstract}
In this review, we focus on elucidating the cardiac function of germline mutations in the PTPN11 gene, encoding the SH2 domain-containing protein tyrosine phosphatase SHP2. PTPN11 mutations cause LEOPARD Syndrome (LS) and Noonan Syndrome (NS), two disorders that are part of a newly classified family of autosomal dominant syndromes termed "RASopathies," which are caused by germline mutations in components of the RAS/RAF/MEK/ERK MAPK pathway. LS and NS mutants have opposing biochemical properties, and yet, in patients, these mutations produce similar cardiac abnormalities. Precisely how LS and NS mutations lead to such similar disease etiology remains largely unknown. Recent complementary in-vitro, ex-vivo and in-vivo analyses reveal new insights into the functions of SHP2 in normal and pathological cardiac development. These findings also reveal the need for individualized therapeutic approaches in the treatment of patients with LS and NS, and more broadly, patients with the other "RASopathy" gene mutations as well.
\end{abstract}

\section{Introduction}

Congenital heart disorders (CHDs) are the most common type of birth defect ( 1/100 live births) and the major cause of birth-related deaths (Weismann and Gelb 2007). Abnormalities in signaling molecules and/or pathways are implicated in CHD pathogenesis; however, underlying mechanisms remain poorly understood and/or unknown. Recently, a new family of autosomal dominant syndromes was recognized, termed "RASopathies" (Figure 1). These disorders, which include LEOPARD Syndrome (LS) (OMIM: 151100) and Noonan Syndrome (NS) (OMIM: 163950), are caused by germline mutations in components of the RAS/RAF/MEK/ERK mitogen activating protein kinase (MAPK) pathway (Tidyman and Rauen 2009), which is required for normal cell growth, differentiation, and survival. Aberrant regulation of this pathway has profound effects, particularly on cardiac development, resulting in various abnormalities, including valvuloseptal defects and/or hypertrophic cardiomyopathy (HCM). With perturbations of the

(C) 2012 Elsevier Inc. All rights reserved.

Address Correspondence to: Dr. Maria Irene Kontaridis, Department of Medicine, Division of Cardiology, Beth Israel Deaconess Medical Center, Center for Life Sciences, Room 908, 3 Blackfan Circle, Boston, MA 02115, Tel: 617-735-4248, Fax: 617-735-4255, mkontari@bidmc.harvard.edu.

The authors wish to disclose that there are no conflicts of interest.

Publisher's Disclaimer: This is a PDF file of an unedited manuscript that has been accepted for publication. As a service to our customers we are providing this early version of the manuscript. The manuscript will undergo copyediting, typesetting, and review of the resulting proof before it is published in its final citable form. Please note that during the production process errors may be discovered which could affect the content, and all legal disclaimers that apply to the journal pertain. 
MAPK signaling pathway established as central to RASopathy disorders, several candidate genes along this canonical pathway have been identified in humans with RASopathy disease phenotypes, including mutations in KRAS, NRAS, SOS1, RAF1, BRAF, MEK1, MEK2, SHOC2, and CBL (Carta et al. 2006; Cirstea et al. 2010; Cordeddu et al. 2009; Dentici et al. 2009; Martinelli et al. 2010; Niihori et al. 2006; Pandit et al. 2007; Razzaque et al. 2007; Roberts et al. 2007; Schubbert et al. 2006; Tartaglia et al. 2007) (Figure 1). The gene most commonly mutated in NS and LS is PTPN11 (Figure 1) (Tartaglia et al. 2001).

\section{PTPN11: Structure and Function}

PTPN11, encoding the Src homology-2 (SH2) domain-containing non-transmembrane protein tyrosine phosphatase (PTP) SHP2. SHP2 is a ubiquitously expressed protein that contains two SH2 domains, a central PTP catalytic domain and a C-terminal tail with two tyrosine phosphorylation sites and a proline-rich motif. Resolution of the crystal structure, along with biochemical validation, has elucidated its mechanism of regulation, whereby in the inactive state, the backside loop of the N-SH2 domain folds into the PTP catalytic pocket rendering SHP2 structurally and biochemically inactive (Hof et al. 1998). Binding of phosphotyrosyl (pY) peptides to the $\mathrm{SH} 2$ domains induces a conformational change, unfolding the structure and thereby allowing substrates access to the catalytic pocket (Neel et al. 2003). The interaction of SHP2 with pY proteins, such as receptor tyrosine kinases (RTK), cytokine receptors and scaffolding adaptors (e.g. insulin receptor substrate 1 (IRS1), GRB2-associated binder 1 (GAB1)), mediates signaling events that control proliferation, differentiation and apoptosis within the cell.

SHP2's regulatory function in intracellular signaling is complicated. Genetic and biochemical evidence well demonstrate that SHP2 is a positive regulator of intracellular signaling pathways and is required for ERK/MAPK pathway activation by most, if not all, RTKs, as well as by cytokine receptors and integrins (Feng 1999; Neel et al. 2003; Tonks and Neel 2001). SHP2 binds directly to some RTKs or, more often, to scaffolds, and becomes activated. Cells expressing dominant negative SHP2 (Noguchi et al. 1994) or Ptpn11 Exon 3 deleted (Ex $3^{-/-}$) mouse embryonic fibroblasts (Shi et al. 2000) exhibit defective RAS activation, suggesting that SHP2 acts upstream of RAS. However, early in vitro experiments showed that a catalytically inactive mutant of SHP2 could perturb (some) components of downstream signaling, even in the presence of a constitutively active RAS, suggesting that SHP2 may also function either downstream and/or in parallel to RAS (Yamauchi et al. 1995). As such, despite extensive study, the precise mechanisms by which SHP2 mediates ERK/MAPK activation remain controversial. SHP2 has been implicated in RTK-evoked src family kinases (SFK) activation, with SFKs, in turn, required for sustained RAS activation (Zhang et al. 2004). Other suggested targets include the RASGap binding sites on some RTKs (Agazie and Hayman 2003; Klinghoffer and Kazlauskas 1995), the Shp Substrate 1 (SHPS-1) glycoprotein (Fujioka et al. 1996; Kontaridis et al. 2001) and the regulatory pY sites on Sprouty proteins, a family of RAS inhibitors (Hanafusa et al. 2004).

Actions of SHP2 on other pathways have also been demonstrated to play a key role in functional regulation. JAK/STAT (Neel et al. 2003), NF-kB (Feng 1999), and RHOA (Kontaridis et al. 2004) signaling have all been proposed. In addition, SHP2 can also regulate activation of the phosphoinositide 3-kinase (PI3K)/AKT pathway in a growth factor-specific manner. In response to epidermal growth factor (EGF), SHP2 negatively regulates PI3K/AKT activation, likely through binding and dephosphorylation of the GAB1 p85 binding sites (Zhang et al. 2002). In contrast, in response to other growth factors such as the platelet-derived growth factor (PDGF) and insulin-like growth factor (IGF), SHP2 evokes a positive regulation on PI3K/AKT activation (Zhang et al. 2002). The basis for this differential regulation on AKT activity by SHP2 is not yet clear. 
Interestingly, and in addition to its role as a phosphatase, there is evidence to suggest that SHP2 can function as an adapter. For example, SHP2 acts as a scaffold for recruitment of the GRB2/SOS complex to the cell membrane through its Tyr542 site in response to PDGF, suggesting a potential alternate mechanism for SHP2 regulation of RAS (Bennett et al. 1994; Li et al. 1994). Similarly, Tyr580 on SHP2 binds GRB2 (Vogel and Ullrich 1996). While intriguing, Araki et. al. demonstrated that SHP2 can only become tyrosyl phosphorylated at these sites in response to some (fibroblast growth factor (FGF), PDGF), but not all (EGF, IGF1) agonists (Araki et al. 2003), suggesting that the tyrosyl phosphorylation sites on SHP2 function to enhance, but not replace, SHP2 catalytic function on downstream signaling in a growth factor-specific manner. The roles, if any, of other functional domains of SHP2 have not yet been determined.

\section{PTPN11 Mutations in Human Disease}

SHP2 mutants have functional significance and, therefore, biological consequences. Heterozygous missense mutations in PTPN11 are observed in up to 90\% of LS cases. LS, a rare autosomal dominant disorder, is an acronym for its presenting features of multiple Lentigines, ECG conduction abnormalities, Ocular hypertelorism, Pulmonic stenosis, A bnormalities of genitalia, Retardation of growth and sensorineural Deafness (Digilio et al. 2002; Legius et al. 2002) and is also referred to as Noonan Syndrome with Multiple Lentigines, Multiple Lentigines Syndrome, and Cardiomyopathic Lentiginosis. 50\% of NS cases are also caused by missense PTPN11 mutations (Tartaglia et al. 2001). In contrast to LS, NS is fairly common ( 1:1000-1:2500 live births) but is also characterized by multiple, variably penetrant defects, including proportionate short stature, facial dysmorphia, and/or CHD (Noonan 1968; Nora et al. 1974).

The most common cardiac manifestation in NS is pulmonic stenosis (PS) resulting from dysplastic valve leaflets, but stenosis of other valves (mitral valve), atrial (ASD), ventricular (VSD) and atrioventricular (AVSD) septal defects or rarely, double outlet right ventricle (DORV), also are seen (Marino et al. 1999) (Yoshida et al. 2004). HCM has also been reported in a few NS patients without SHP2 mutations (Tartaglia et al. 2002), but genotypephenotype correlation studies show that only $8 \%$ of SHP2 associated-NS patients present with HCM (Sznajer et al. 2007) (Table 1). In contrast, most cases of LS present with HCM, but similar valve anomalies to NS are also observed (Limongelli et al. 2007) (Table 1).

Why "hot spot" mutations within SHP2 lead to a disease phenotype is likely due to the fact that the mutations evoke a loss of negative regulation by SHP2. Whether PTPN11 itself serves as a "hot spot" for such mutations is not known; but speculatively, mutations in PTPN11 may be favored because, like other genes already identified along the RAS signaling pathway, 1) missense defects can give rise to gain of function capabilitites, 2) functional missense changes are mild enough as to not be embryonic lethal, 3) mutations may give spermatogonia a competitive advantage (Wilkie 1997), and/or 4) cells carrying these mutations may be favored during germ-line mitotic divisions (Wilkie 1997).

\section{NS and LS: differential mechanisms of PTPN11 regulation}

Because NS and LS share such similar phenotypic characteristics in patients, they were considered to have similar disease pathogenesis. Interestingly, the point mutations identified in PTPN11 that were associated with NS were distinct from those associated with LS (Table 2). Indeed, the biochemical properties between the PTPN11 NS- and LS-specific point mutations are quite different (Hanna et al. 2006; Kontaridis et al. 2006; Tartaglia et al. 2006). Most NS mutations reside within the N-SH2 domain interface that allows for the intermolecular interactions with the PTP domain. Therefore, NS mutations disrupt the ability of SHP2 to retain the closed, inactive conformation without affecting PTP enzymatic 
activity. As a result, NS mutations behave as gain-of-function (GOF) alleles with increased basal phosphatase activity (Keilhack et al. 2005).

In contrast, all LS mutations tested were catalytically inactive, with decreased and/or absent PTP catalytic activity that resulted in a loss-of-function (LOF) of the phosphatase. Indeed, LS mutants affect conserved residues important for PTP catalysis (e.g. Y279, which sets the depth of the catalytic cleft; T468, which lies within the area of the "signature motif.") (Table 2) (Hanna et al. 2006; Kontaridis et al. 2006; Tartaglia et al. 2006). However, like the mutants associated with NS, LS mutations also perturb N-SH2/PTP domain interactions, suggesting that both NS and LS mutants can out-compete WT SHP2 for binding to RTKs/ scaffolds (Kontaridis et al. 2006; Marin et al. 2011)

Understanding precisely how it is that GOF and LOF mutations lead to such similar clinical phenotypes is of great clinical importance. Attention has naturally focused on the ERK/ MAPK pathway in explaining the pathogenesis of RASopathies. However, different RASopathies can have complex and distinct effects on multiple cellular signaling pathways. Knowledge of the detailed effects of these mutations on downstream molecular and cellular signaling events is essential for a more rational and personalized approach to therapy for these disorders.

\section{Modeling LS-associated cardiac hypertrophy}

Interestingly, initial in vivo studies reported conflicting results on the PTP function of the LS mutations in PTPN11. In contrast to the in vitro studies that provocatively suggested that LS mutations were LOF (Hanna et al. 2006; Kontaridis et al. 2006; Tartaglia et al. 2006), expression of the LS mutants Y279C or T468M in Drosophila resulted in ectopic wing veins and a rough eye phenotype, characteristics of increased ERK/MAPK activity in these tissues. In addition, genetic analysis of enhancers and suppressers were consistent with hypermorphism of the ERK/MAPK pathway in these mutant flies (Oishi et al. 2009). However, LS mutants of shp2 in zebrafish were found to have dominant negative effects (Jopling et al. 2007; Stewart et al. 2010), consistent with the in vitro studies. Recent experiments using induced pluripotent stem cells (iPSCs) from LS patient-derived fibroblasts showed both possibilities, with higher basal, but abrogated agonist-evoked, pERK levels when compared with control iPSCs (Carvajal-Vergara et al. 2011). The precise reasons for these signaling discrepancies are not yet entirely clear, but might relate to species differences, cell-type specificity and/or the effects of over-expression.

In an effort to resolve this conundrum, we generated the first mammalian model of LS by inducibly knocking-in a PTPN11 allele harboring the LS Y279C mutation in mice (iLS/+) (Marin et al. 2011). When crossed to EIIA deleter-Cre mice, these (now termed) LS/+ mice recapitulated nearly all aspects of the human LS phenotype, including hypertrophic cardiomyopathy (HCM). LS/+ mice also had short stature, craniofacial dysmorphia, and skeletal abnormalities, consistent with LS in human patients (Gorlin et al. 1971; Tartaglia and Gelb 2005). Importantly, heart and/or cardiomyocyte lysates from LS/+ mice showed decreased SHP2 catalytic activity, suggesting that LS mutants are indeed catalytically inactive in vivo. Biochemical analyses revealed that the LS/+ mutant hearts and/or cardiomyocytes showed enhanced binding of SHP2 to the scaffolding adapter proteins Gab-1 and IRS-1 and had abrogated agonist-evoked ERK/MAPK activation (Figure 2), consistent with previous in vitro reports (Hanna et al. 2006; Kontaridis et al. 2006; Tartaglia et al. 2006). By contrast, and different from NS biochemistry, AKT/mTOR signaling was enhanced significantly in LS/+ hearts, as well as in cardiomyocytes, consistent with in vivo findings in fibroblasts isolated from LS patients (Edouard et al. 2010). In addition, we found increased phosphorylation of FAK, STAT3 and JNK1/2 (Figure 2), all signaling molecules 
that are also implicated in cardiomyopathy ( $\mathrm{Ng}$ et al. 2003; Wang et al. 1998). Although there is a possibility that these other signaling pathways play a contributory role in the development of HCM in vivo, we found that inhibiting mTOR signaling with rapamycin, an immunosuppressant drug that specifically targets and suppresses TOR activity, completely normalized and reversed the LS cardiac defects. These data directly implicate excessive AKT/mTOR activity, and not ERK/MAPK, in LS pathogenesis. Further, they suggest that therapeutic efficacy of rapamycin and/or its derivatives should be evaluated in LS patients specifically.

More recently, Ishida et. al. analyzed the effects of yet another LS PTPN11 mutant, the Gln510Glu (Q510E) mutation, and also found that this LS mutation evokes a severe HCM in their cardiomyocyte differentiation model system (Ishida et al. 2011). In addition, the Q510E mutants differentiated into cardiac progenitors, but were unable to undergo terminal differentiation into mature cardiomyocytes, suggesting that LS mutations may have an effect on cardiac progenitor expansion. Here too, however, activity of AKT and its downstream effector, glycogen synthase kinase (GSK)-3 $\beta$, were upregulated. In these experiments, upstream inhibition of the pathway with the PI3K/AKT inhibitor LY-294002 partially rescued the hypertrophic defect (Ishida et al. 2011). These findings were further validated in an in vivo characterization of the Q510E mutation using a transgenic overexpression mouse model showing that prenatal, but not postnatal, overexpression of the Q510E mutation causes enlargement of cardiomyocytes, an increase in heart-to-body weight ratio, and thicker interventricular septum (Schramm et al. 2012). Here again, the biochemical signaling pathway most robustly affected by the LS mutation in PTPN11 is the AKT/mTOR pathway (Schramm et al. 2012). Taken together, the combined in vitro, ex vivo, and in vivo data all confirm that 1) LS mutations primarily affect the AKT/mTOR signaling pathway, not the ERK/MAPK pathway and 2) the cardiac abnormalities associated with LS, namely HCM, can be treated and reversed with a TOR inhibitor such as rapamycin.

\section{Modeling NS-associated cardiac hypertrophy}

Biochemical, cell biological and genetic evidence indicate that PTPN11 mutations associated with NS are hypermorphs that can enhance ERK/MAPK pathway activation (Keilhack et al. 2005). However, differing NS PTPN11 mutations appear to result in uniquely differing cardiac phenotypes (Araki et al. 2009; Araki et al. 2004; Krenz et al. 2008). For example, $~ 50 \%$ of the knock-in mice for the Ptpn 11 D61G NS exhibit valvuloseptal defects similar to those observed in NS patients, but with no evidence of HCM (Araki et al. 2004). Overexpression of PTPN11 Q79R in the developing endocardial cushions show significantly enlarged endocardial cushions in the atrioventricular canal and in the outflow tract (Krenz et al. 2008), whereas overexpression in the developing myocardium causes ventricular noncompaction, myocardial thinning and ventricular septal defects without evidence of HCM (Nakamura et al. 2007). Nevertheless, breeding the Ptpn11 Q79R mice into ERK1/2-null backgrounds confirmed that the MAPK/ERK pathway is indeed causative to NS. Moreover, constitutive activation of ERK1/2 through MEK1 overexpression during valve development results in an NS-like phenotype (Krenz et al. 2008), whereas transgenic overexpression in adult hearts leads to HCM (Bueno et al. 2000). Interestingly, absence of Ptpn11 in cardiomyocytes also causes a pathological cardiac phenotype; hearts from mice with SHP2-cardiomyocyte specific deletion (using the cardiomyocyte specific promoter alpha myosin heavy chain (aMHC)-Cre recombinase) develop severe dilatation (Kontaridis et al. 2008), suggesting a causal role for PTPN11 in cardiomyocyte regulation and hypertrophy.

The differential expression of the individual mutants, and/or their levels of activity, localization, and feedback regulation in different cell/tissue types, may account somewhat 
for the variable severity and/or phenotype in each RASopathy. NS-associated HCM does occur, however, usually in other RASopathy gene mutations. Knock-in mice expressing the NS-associated Sos 1-E846K mice develop HCM with incompletely penetrant aortic stenosis (Chen et al. 2010) Mice expressing the NS-associated Raf1L613V allele develop HCM, but with normal valvuloseptal development (Wu et al. 2011). Assessment of ERK/MAPK signaling in vitro and in vivo in hearts from these mice revealed increased activation of Mek1/2 and ERK1/2, suggesting that blockade of the ERK/MAPK signaling pathway in these mice could be beneficial. Indeed, treatment with the MEK inhibitor, PD0325901, blocked and reversed HCM in vivo (Wu et al. 2011).

Dhandapany, et. al., further explored the ability of the NS/LS Raf1 mutants S257L, L613V, and D486N mutants to regulate hypertrophy in cardiomyocytes (Dhandapany et al. 2011). Interestingly, they found that the two mutants associated with HCM in NS/LS patients, the L613V and S257L mutations, also promoted NFAT signaling and interacted with calcineurin in co-immunoprecipitation studies. Furthermore, treatment with the calcineurin inhibitor cyclosporine-A prevented RAF1-induced hypertrophy in neonatal cardiomyocytes (Dhandapany et al. 2011). Taken together, these studies suggest the intriguing possibility that canonical MAPK signaling may not be the sole driver for NS-associated HCM.

\section{RASopathies: future therapeutic intervention for NS and LS}

Collectively, the results of these studies raise awareness for the need for treatment of diseases and disorders based on biochemical, rather than phenotypic presentation. This provides further impetus to proceed with efforts to identify the other disease genes underlying these disorders and to generate animal models as well as human cell model systems. For example, the continued development of iPSC technology might enable a deeper understanding of the molecular mechanisms underlying human disease, as well as improve our ability to achieve successful individualized therapies for treating patients. Ultimately, it will be the combination of understanding the pathogenesis of each disorder and the identification of small molecules that will enable us to treat patients.

Aside from enabling genetic testing for these RASopathy disorders, genotype/phenotype associations have been established for many, but much work is left to be done. These types of observations allow us to raise important biological and clinical questions. How are tissues/organs differentially affected by specific RASopathy mutations? If proteins are ubiquitously expressed, why are some organs/tissues spared while others are severely impacted? What is the basis of the specificity between altered gene, or even specific mutation, and the phenotype? How do we determine which pathways are affected by each of the mutations? Can inhibition of these ameliorate features of the disorders, and without side affects?

For treatment of NS-associated hypertrophy where the cause is associated with increased activation of MEK1/2 and/or ERK1/2, blockade of MAPK signaling seems efficacious. Indeed, in the Raf1L $613 \mathrm{~V}$ model, treatment of the mice with the MEK inhibitor, PD0325901, blocked emergence of HCM as well as reversed it. However, clinical trials with PD325901 for the treatment of several types of cancers were terminated early due to ophthalmologic and neurologic toxicity (Haura et al. 2010). Therefore, since RAS/MAPK signaling is present in a wide array of normal cells and RAS proteins control multiple cellular processes and target several downstream effectors, titrating down to the right level of inhibition to provide therapeutic efficacy without incurring intolerable side effects will be critical to maintain therapeutic advantage. Alternatively, more specifically targeted (and therefore more tolerable) drugs for this pathway are currently in the pipeline. 
LS models, on the other hand, support the conclusion that excessive AKT/mTOR activity, not MAPK, is essential for the development and maintenance of HCM, and that a potential effective treatment for the reversal of HCM in these patients is rapamycin and/or its analogs. Rapamycin is commonly used as an immunosuppressive drug (Alexandre et al. 1999). Nevertheless, it also has been used for other purposes, both in animal models and humans. Rapamycin has proven safe and beneficial in several therapeutic protocols; for instance, rapamycin is used for treatment of polycystic kidney disease in clinical trials (Serra et al. 2007) and a rapamycin analog is now approved for the treatment of renal cancer (Dancey et al. 2009).

Previous pharmacological studies have shown that treatment of cardiomyocytes with rapamycin could inhibit the hypertrophic response evoked by stimulation with various agonists (Boluyt et al. 1997; Sadoshima and Izumo 1995; Wang and Proud 2002; Wang et al. 2000). Rapamycin has also been shown to attenuate or reverse pressure overload- or constitutively active AKT-induced cardiac hypertrophy (Soesanto et al. 2009) (Gao et al. 2006; Shioi et al. 2003), supporting a potential regulatory role for mTOR in HCM.

However, recent evidence argues that mTOR expression either has no effect (Shen et al. 2008) or may even be protective against stressed-induced pathological hypertrophy (Song et al. 2010). Indeed, two independent studies indicate that complete ablation of mTOR (Zhang et al. 2010) or the regulator of mTORC1, RAPTOR (Shende et al. 2011), leads to DCM. These findings imply that rapamycin could have detrimental effects, and as a result, we cannot exclude the possibility that chronic inhibition and/or inhibition below physiological levels of mTOR could be deleterious in vivo. Consequently, chronic and/or high-dosed inhibition of mTOR in patients with severe HCM and/or compromised contractile function may not be advisable. However, in the animal models of LS described herein, acute and/or low-dose administration of rapamycin was indeed able to rescue the hypertrophic phenotype without adverse effects on cardiac function (Marin et al. 2011; Schramm et al. 2012). Therefore, a potential short term and/or low-dose administration of rapamycin could have advantageous and beneficial effects in LS patients. Taken together, clinical trials of rapamycin and/or analogs should be considered for the treatment of LS-associated HCM.

We have made significant progress in understanding the differential signaling mechanisms affected by specific mutations in RASopathy disorders. We still have a long way to go. But given what we have learned so far, it is clear that the strategy for therapy must be based on the elucidation of the biological mechanism evoked by each specific mutation, rather than the physiological characteristics of the disorder itself.

\section{Acknowledgments}

This work was supported by National Institutes of Health Grants HL088514, the Milton Fund and the Beth Israel Deaconess Medical Center Division of Cardiology (to M.I.K.).

\section{References}

Agazie YM, Hayman MJ. Molecular mechanism for a role of SHP2 in epidermal growth factor receptor signaling. Mol Cell Biol. 2003; 23:7875-86. [PubMed: 14560030]

Alexandre J, Raymond E, Armand JP. Rapamycin and CCI-779. Bull Cancer. 1999; 86:808-11. [PubMed: 10572230]

Araki T, Chan G, Newbigging S, Morikawa L, Bronson RT, Neel BG. Noonan syndrome cardiac defects are caused by PTPN11 acting in endocardium to enhance endocardial-mesenchymal transformation. Proc Natl Acad Sci U S A. 2009; 106:4736-41. [PubMed: 19251646]

Araki T, Mohi MG, Ismat FA, Bronson RT, Williams IR, Kutok JL, Yang W, Pao LI, Gilliland DG, Epstein JA, et al. Mouse model of Noonan syndrome reveals cell type- and gene dosage-dependent effects of Ptpn11 mutation. Nat Med. 2004; 10:849-57. [PubMed: 15273746] 
Araki T, Nawa H, Neel BG. Tyrosyl phosphorylation of Shp2 is required for normal ERK activation in response to some, but not all, growth factors. J Biol Chem. 2003; 278:41677-84. [PubMed: 12923167]

Bennett AM, Tang TL, Sugimoto S, Walsh CT, Neel BG. Protein-tyrosine-phosphatase SHPTP2 couples platelet-derived growth factor receptor $\beta$ to Ras. Proceedings of the National Academy of Science of the United States of America. 1994; 91:7335-7339.

Boluyt MO, Zheng JS, Younes A, Long X, O’Neill L, Silverman H, Lakatta EG, Crow MT. Rapamycin inhibits alpha 1-adrenergic receptor-stimulated cardiac myocyte hypertrophy but not activation of hypertrophy-associated genes. Evidence for involvement of p70 S6 kinase. Circ Res. 1997; 81:176-86. [PubMed: 9242178]

Bueno OF, De Windt LJ, Tymitz KM, Witt SA, Kimball TR, Klevitsky R, Hewett TE, Jones SP, Lefer DJ, Peng CF, et al. The MEK1-ERK1/2 signaling pathway promotes compensated cardiac hypertrophy in transgenic mice. Embo J. 2000; 19:6341-50. [PubMed: 11101507]

Carta C, Pantaleoni F, Bocchinfuso G, Stella L, Vasta I, Sarkozy A, Digilio C, Palleschi A, Pizzuti A, Grammatico P, et al. Germline missense mutations affecting KRAS Isoform B are associated with a severe Noonan syndrome phenotype. Am J Hum Genet. 2006; 79:129-35. [PubMed: 16773572]

Carvajal-Vergara X, Sevilla A, D’Souza SL, Ang YS, Schaniel C, Lee DF, Yang L, Kaplan AD, Adler ED, Rozov R, et al. Patient-specific induced pluripotent stem-cell-derived models of LEOPARD syndrome. Nature. 2011; 465:808-12. [PubMed: 20535210]

Chen PC, Wakimoto H, Conner D, Araki T, Yuan T, Roberts A, Seidman CE, Bronson R, Neel BG, Seidman JG, et al. Activation of multiple signaling pathways causes developmental defects in mice with a Noonan syndrome-associated Sos 1 mutation. J Clin Invest. 2010

Cirstea IC, Kutsche K, Dvorsky R, Gremer L, Carta C, Horn D, Roberts AE, Lepri F, MerbitzZahradnik T, Konig R, et al. A restricted spectrum of NRAS mutations causes Noonan syndrome. Nat Genet. 2010; 42:27-9. [PubMed: 19966803]

Cordeddu V, Di Schiavi E, Pennacchio LA, Ma'ayan A, Sarkozy A, Fodale V, Cecchetti S, Cardinale A, Martin J, Schackwitz W, et al. Mutation of SHOC2 promotes aberrant protein N-myristoylation and causes Noonan-like syndrome with loose anagen hair. Nat Genet. 2009; 41:1022-6. [PubMed: 19684605]

Dancey JE, Curiel R, Purvis J. Evaluating temsirolimus activity in multiple tumors: a review of clinical trials. Semin Oncol. 2009; 36(Suppl 3):S46-58. [PubMed: 19963100]

Darian E, Guvench O, Yu B, Qu CK, MacKerell AD Jr. Structural mechanism associated with domain opening in gain-of-function mutations in SHP2 phosphatase. Proteins. 2011; 79:1573-88. [PubMed: 21365683]

Dentici ML, Sarkozy A, Pantaleoni F, Carta C, Lepri F, Ferese R, Cordeddu V, Martinelli S, Briuglia $\mathrm{S}$, Digilio MC, et al. Spectrum of MEK1 and MEK2 gene mutations in cardio-facio-cutaneous syndrome and genotype-phenotype correlations. Eur J Hum Genet. 2009; 17:733-40. [PubMed: 19156172]

Dhandapany PS, Fabris F, Tonk R, Illaste A, Karakikes I, Sorourian M, Sheng J, Hajjar RJ, Tartaglia M, Sobie EA, et al. Cyclosporine attenuates cardiomyocyte hypertrophy induced by RAF1 mutants in Noonan and LEOPARD syndromes. J Mol Cell Cardiol. 2011; 51:4-15. [PubMed: 21440552]

Digilio MC, Conti E, Sarkozy A, Mingarelli R, Dottorini T, Marino B, Pizzuti A, Dallapiccola B. Grouping of multiple-lentigines/LEOPARD and Noonan syndromes on the PTPN11 gene. Am J Hum Genet. 2002; 71:389-94. [PubMed: 12058348]

Edouard T, Combier JP, Nedelec A, Bel-Vialar S, Metrich M, Conte-Auriol F, Lyonnet S, Parfait B, Tauber M, Salles JP, et al. Functional effects of PTPN11 (SHP2) mutations causing LEOPARD syndrome on epidermal growth factor-induced phosphoinositide 3-kinase/AKT/glycogen synthase kinase 3beta signaling. Mol Cell Biol. 2010; 30:2498-507. [PubMed: 20308328]

Feng G. SHP-2 Tyrosine Phosphatase: Signaling One Cell or Many. Experimental Cell Research. 1999; 253:47-54. [PubMed: 10579910]

Fujioka Y, Matozaki T, Noguchi T, Iwamatsu A, Yamao T, Takahashi N, Tsuda M, Takada T, Kasuga M. A novel membrane glycoprotein, SHPS-1, that binds the SH2-domain-containing protein tyrosine phosphatase SHP-2 in response to mitogens and cell adhesion. Molecular and Celluar Biology. 1996; 16:6887-6899. 
Gao XM, Wong G, Wang B, Kiriazis H, Moore XL, Su YD, Dart A, Du XJ. Inhibition of mTOR reduces chronic pressure-overload cardiac hypertrophy and fibrosis. J Hypertens. 2006; 24:166370. [PubMed: 16877971]

Gorlin RJ, Anderson RC, Moller JH. The Leopard (multiple lentigines) syndrome revisited. Birth Defects Orig Artic Ser. 1971; 07:110-5. [PubMed: 5173334]

Hanafusa H, Torii S, Yasunaga T, Matsumoto K, Nishida E. Shp2, an SH2-containing protein-tyrosine phosphatase, positively regulates receptor tyrosine kinase signaling by dephosphorylating and inactivating the inhibitor Sprouty. J Biol Chem. 2004; 279:22992-5. [PubMed: 15031289]

Hanna N, Montagner A, Lee WH, Miteva M, Vidal M, Vidaud M, Parfait B, Raynal P. Reduced phosphatase activity of SHP-2 in LEOPARD syndrome: consequences for PI3K binding on Gab1. FEBS Lett. 2006; 580:2477-82. [PubMed: 16638574]

Haura EB, Ricart AD, Larson TG, Stella PJ, Bazhenova L, Miller VA, Cohen RB, Eisenberg PD, Selaru P, Wilner KD, et al. A phase II study of PD-0325901, an oral MEK inhibitor, in previously treated patients with advanced non-small cell lung cancer. Clin Cancer Res. 2010; 16:2450-7. [PubMed: 20332327]

Hof P, Pluskey S, Dhe-Pagganon S, Eck MJ, Shoelson SE. Crystal Structure of the Tyrosine Phosphatase SHP-2. Cell. 1998; 92:441-450. [PubMed: 9491886]

Ishida H, Kogaki S, Narita J, Ichimori H, Nawa N, Okada Y, Takahashi K, Ozono K. LEOPARD-type SHP2 mutant Gln510Glu attenuates cardiomyocyte differentiation and promotes cardiac hypertrophy via dysregulation of Akt/GSK-3beta/beta-catenin signaling. Am J Physiol Heart Circ Physiol. 2011; 301:H1531-9. [PubMed: 21803945]

Jopling C, van Geemen D, den Hertog J. Shp2 knockdown and Noonan/LEOPARD mutant Shp2induced gastrulation defects. PLoS Genet. 2007; 3:e225. [PubMed: 18159945]

Keilhack H, David FS, McGregor M, Cantley LC, Neel BG. Diverse biochemical properties of Shp2 mutants. Implications for disease phenotypes. J Biol Chem. 2005; 280:30984-93. [PubMed: 15987685]

Klinghoffer RA, Kazlauskas A. Identification of a putative Syp substrate, the PDGF $\beta$ receptor. Journal of Biological Chemistry. 1995; 270:22208-22217. [PubMed: 7545675]

Kontaridis MI, Eminaga S, Fornaro M, Zito CI, Sordella R, Settleman J, Bennett AM. SHP-2 positively regulates myogenesis by coupling to the Rho GTPase signaling pathway. Mol Cell Biol. 2004; 24:5340-52. [PubMed: 15169898]

Kontaridis MI, Liu X, Zhang L, Bennett AM. SHP-2 complex formation with the SHP-2 substrate-1 during C2C12 myogenesis. J Cell Sci. 2001; 114:2187-98. [PubMed: 11493654]

Kontaridis MI, Swanson KD, David FS, Barford D, Neel BG. PTPN11 (Shp2) mutations in LEOPARD syndrome have dominant negative, not activating, effects. J Biol Chem. 2006; 281:6785-92. [PubMed: 16377799]

Kontaridis MI, Yang W, Bence KK, Cullen D, Wang B, Bodyak N, Ke Q, Hinek A, Kang PM, Liao R, et al. Deletion of Ptpn11 (Shp2) in cardiomyocytes causes dilated cardiomyopathy via effects on the extracellular signal-regulated kinase/mitogen-activated protein kinase and RhoA signaling pathways. Circulation. 2008; 117:1423-35. [PubMed: 18316486]

Krenz M, Gulick J, Osinska HE, Colbert MC, Molkentin JD, Robbins J. Role of ERK1/2 signaling in congenital valve malformations in Noonan syndrome. Proc Natl Acad Sci U S A. 2008; 105:18930-5. [PubMed: 19017799]

Legius E, Schrander-Stumpel C, Schollen E, Pulles-Heintzberger C, Gewillig M, Fryns JP. PTPN11 mutations in LEOPARD syndrome. J Med Genet. 2002; 39:571-4. [PubMed: 12161596]

Li W, Nishimura R, Kashishian A, Batzer AG, Kim WJ, Cooper JA, Schlessinger J. A new function for a phosphotyrosine phosphatase: linking GRB2-Sos to a receptor tyrosine kinase. Molecular and cellular biology. 1994; 14:509-17. [PubMed: 8264620]

Limongelli G, Pacileo G, Marino B, Digilio MC, Sarkozy A, Elliott P, Versacci P, Calabro P, De Zorzi A, Di Salvo G, et al. Prevalence and clinical significance of cardiovascular abnormalities in patients with the LEOPARD syndrome. Am J Cardiol. 2007; 100:736-41. [PubMed: 17697839]

Marin TM, Keith K, Davies B, Conner DA, Guha P, Kalaitzidis D, Wu X, Lauriol J, Wang B, Bauer $\mathrm{M}$, et al. Rapamycin reverses hypertrophic cardiomyopathy in a mouse model of LEOPARD 
syndrome-associated PTPN11 mutation. The Journal of clinical investigation. 2011; 121:1026-43. [PubMed: 21339643]

Marino B, Digilio MC, Toscano A, Giannotti A, Dallapiccola B. Congenital heart diseases in children with Noonan syndrome: An expanded cardiac spectrum with high prevalence of atrioventricular canal. J Pediatr. 1999; 135:703-6. [PubMed: 10586172]

Martinelli S, De Luca A, Stellacci E, Rossi C, Checquolo S, Lepri F, Caputo V, Silvano M, Buscherini $\mathrm{F}$, Consoli $\mathrm{F}$, et al. Heterozygous germline mutations in the CBL tumor-suppressor gene cause a Noonan syndrome-like phenotype. Am J Hum Genet. 2010; 87:250-7. [PubMed: 20619386]

Nakamura T, Colbert M, Krenz M, Molkentin JD, Hahn HS, Dorn GW 2nd, Robbins J. Mediating ERK 1/2 signaling rescues congenital heart defects in a mouse model of Noonan syndrome. The Journal of clinical investigation. 2007; 117:2123-32. [PubMed: 17641779]

Neel BG, Gu H, Pao L. The 'Shp'ing news: SH2 domain-containing tyrosine phosphatases in cell signaling. Trends Biochem Sci. 2003; 28:284-93. [PubMed: 12826400]

$\mathrm{Ng}$ DC, Court NW, dos Remedios CG, Bogoyevitch MA. Activation of signal transducer and activator of transcription (STAT) pathways in failing human hearts. Cardiovasc Res. 2003; 57:333-46. [PubMed: 12566106]

Niihori T, Aoki Y, Narumi Y, Neri G, Cave H, Verloes A, Okamoto N, Hennekam RC, GillessenKaesbach G, Wieczorek D, et al. Germline KRAS and BRAF mutations in cardio-facio-cutaneous syndrome. Nat Genet. 2006; 38:294-6. [PubMed: 16474404]

Noguchi T, Matozaki T, Horita K, Fujioka Y, Kasuga M. Role of SH-PTP2, a protein-tyrosine phosphatase with src homology 2 domains, in insulin-stimulated ras activation. Molecular and Celluar Biology. 1994; 14:6674-6682.

Noonan JA. Hypertelorism with Turner phenotype. A new syndrome with associated congenital heart disease. Am J Dis Child. 1968; 116:373-80. [PubMed: 4386970]

Nora JJ, Nora AH, Sinha AK, Spangler RD, Lubs HA. The Ullrich-Noonan syndrome (Turner phenotype). Am J Dis Child. 1974; 127:48-55. [PubMed: 4809794]

Oishi K, Zhang H, Gault WJ, Wang CJ, Tan CC, Kim IK, Ying H, Rahman T, Pica N, Tartaglia M, et al. Phosphatase-defective LEOPARD syndrome mutations in PTPN11 gene have gain-of-function effects during Drosophila development. Hum Mol Genet. 2009; 18:193-201. [PubMed: 18849586]

Pandit B, Sarkozy A, Pennacchio LA, Carta C, Oishi K, Martinelli S, Pogna EA, Schackwitz W, Ustaszewska A, Landstrom A, et al. Gain-of-function RAF1 mutations cause Noonan and LEOPARD syndromes with hypertrophic cardiomyopathy. Nat Genet. 2007; 39:1007-12. [PubMed: 17603483]

Razzaque MA, Nishizawa T, Komoike Y, Yagi H, Furutani M, Amo R, Kamisago M, Momma K, Katayama H, Nakagawa M, et al. Germline gain-of-function mutations in RAF1 cause Noonan syndrome. Nat Genet. 2007; 39:1013-7. [PubMed: 17603482]

Roberts AE, Araki T, Swanson KD, Montgomery KT, Schiripo TA, Joshi VA, Li L, Yassin Y, Tamburino AM, Neel BG, et al. Germline gain-of-function mutations in SOS1 cause Noonan syndrome. Nat Genet. 2007; 39:70-4. [PubMed: 17143285]

Sadoshima J, Izumo S. Rapamycin selectively inhibits angiotensin II-induced increase in protein synthesis in cardiac myocytes in vitro. Potential role of 70-kD S6 kinase in angiotensin II-induced cardiac hypertrophy. Circ Res. 1995; 77:1040-52. [PubMed: 7586215]

Sarkozy A, Conti E, Digilio MC, Marino B, Morini E, Pacileo G, Wilson M, Calabro R, Pizzuti A, Dallapiccola B. Clinical and molecular analysis of 30 patients with multiple lentigines LEOPARD syndrome. J Med Genet. 2004; 41:e68. [PubMed: 15121796]

Schramm C, Fine DM, Edwards MA, Reeb AN, Krenz M. The PTPN11 loss-of-function mutation Q510E-Shp2 causes hypertrophic cardiomyopathy by dysregulating mTOR signaling. Am J Physiol Heart Circ Physiol. 2012; 302:H231-43. [PubMed: 22058153]

Schubbert S, Zenker M, Rowe SL, Boll S, Klein C, Bollag G, van der Burgt I, Musante L, Kalscheuer V, Wehner LE, et al. Germline KRAS mutations cause Noonan syndrome. Nat Genet. 2006; 38:331-6. [PubMed: 16474405]

Serra AL, Kistler AD, Poster D, Struker M, Wuthrich RP, Weishaupt D, Tschirch F. Clinical proof-ofconcept trial to assess the therapeutic effect of sirolimus in patients with autosomal dominant 
polycystic kidney disease: SUISSE ADPKD study. BMC Nephrol. 2007; 8:13. [PubMed: 17868472]

Shen WH, Chen Z, Shi S, Chen H, Zhu W, Penner A, Bu G, Li W, Boyle DW, Rubart M, et al. Cardiac restricted overexpression of kinase-dead mammalian target of rapamycin (mTOR) mutant impairs the mTOR-mediated signaling and cardiac function. J Biol Chem. 2008; 283:13842-9. [PubMed: 18326485]

Shende P, Plaisance I, Morandi C, Pellieux C, Berthonneche C, Zorzato F, Krishnan J, Lerch R, Hall MN, Ruegg MA, et al. Cardiac raptor ablation impairs adaptive hypertrophy, alters metabolic gene expression, and causes heart failure in mice. Circulation. 2011; 123:1073-82. [PubMed: 21357822]

Shi ZQ, Yu DH, Park M, Marshall M, Feng GS. Molecular mechanism for the Shp-2 tyrosine phosphatase function in promoting growth factor stimulation of Erk activity. Mol Cell Biol. 2000; 20:1526-36. [PubMed: 10669730]

Shioi T, McMullen JR, Tarnavski O, Converso K, Sherwood MC, Manning WJ, Izumo S. Rapamycin attenuates load-induced cardiac hypertrophy in mice. Circulation. 2003; 107:1664-70. [PubMed: 12668503]

Soesanto W, Lin HY, Hu E, Lefler S, Litwin SE, Sena S, Abel ED, Symons JD, Jalili T. Mammalian target of rapamycin is a critical regulator of cardiac hypertrophy in spontaneously hypertensive rats. Hypertension. 2009; 54:1321-7. [PubMed: 19884565]

Song X, Kusakari Y, Xiao CY, Kinsella SD, Rosenberg MA, Scherrer-Crosbie M, Hara K, Rosenzweig A, Matsui T. mTOR attenuates the inflammatory response in cardiomyocytes and prevents cardiac dysfunction in pathological hypertrophy. Am J Physiol Cell Physiol. 2010; 299:C1256-66. [PubMed: 20861467]

Stewart RA, Sanda T, Widlund HR, Zhu S, Swanson KD, Hurley AD, Bentires-Alj M, Fisher DE, Kontaridis MI, Look AT, et al. Phosphatase-dependent and -independent functions of Shp2 in neural crest cells underlie LEOPARD syndrome pathogenesis. Dev Cell. 2010; 18:750-62. [PubMed: 20493809]

Sznajer Y, Keren B, Baumann C, Pereira S, Alberti C, Elion J, Cave H, Verloes A. The spectrum of cardiac anomalies in Noonan syndrome as a result of mutations in the PTPN11 gene. Pediatrics. 2007; 119:e1325-31. [PubMed: 17515436]

Tartaglia M, Gelb BD. Noonan syndrome and related disorders: genetics and pathogenesis. Annu Rev Genomics Hum Genet. 2005; 6:45-68. [PubMed: 16124853]

Tartaglia M, Kalidas K, Shaw A, Song X, Musat DL, van der Burgt I, Brunner HG, Bertola DR, Crosby A, Ion A, et al. PTPN11 mutations in Noonan syndrome: molecular spectrum, genotypephenotype correlation, and phenotypic heterogeneity. Am J Hum Genet. 2002; 70:1555-63. [PubMed: 11992261]

Tartaglia M, Martinelli S, Stella L, Bocchinfuso G, Flex E, Cordeddu V, Zampino G, Burgt I, Palleschi A, Petrucci TC, et al. Diversity and functional consequences of germline and somatic PTPN11 mutations in human disease. Am J Hum Genet. 2006; 78:279-90. [PubMed: 16358218]

Tartaglia M, Mehler EL, Goldberg R, Zampino G, Brunner HG, Kremer H, van der Burgt I, Crosby AH, Ion A, Jeffery S, et al. Mutations in PTPN11, encoding the protein tyrosine phosphatase SHP-2, cause Noonan syndrome. Nat Genet. 2001; 29:465-8. [PubMed: 11704759]

Tartaglia M, Pennacchio LA, Zhao C, Yadav KK, Fodale V, Sarkozy A, Pandit B, Oishi K, Martinelli S, Schackwitz W, et al. Gain-of-function SOS1 mutations cause a distinctive form of Noonan syndrome. Nat Genet. 2007; 39:75-9. [PubMed: 17143282]

Tidyman WE, Rauen KA. The RASopathies: developmental syndromes of Ras/MAPK pathway dysregulation. Curr Opin Genet Dev. 2009; 19:230-6. [PubMed: 19467855]

Tonks NK, Neel BG. Combinatorial control of the specificity of protein tyrosine phosphatases. Curr Opin Cell Biol. 2001; 13:182-95. [PubMed: 11248552]

Vogel W, Ullrich A. Multiple in vivo phosphorylated tyrosine phosphatase SHP-2 engages binding to Grb2 via tyrosine 584. Cell Growth Differ. 1996; 7:1589-97. [PubMed: 8959326]

Wang L, Proud CG. Ras/Erk signaling is essential for activation of protein synthesis by Gq proteincoupled receptor agonists in adult cardiomyocytes. Circ Res. 2002; 91:821-9. [PubMed: 12411397] 
Wang L, Wang X, Proud CG. Activation of mRNA translation in rat cardiac myocytes by insulin involves multiple rapamycin-sensitive steps. Am J Physiol Heart Circ Physiol. 2000; 278:H105668. [PubMed: 10749698]

Wang Y, Su B, Sah VP, Brown JH, Han J, Chien KR. Cardiac hypertrophy induced by mitogenactivated protein kinase kinase 7, a specific activator for c-Jun NH2-terminal kinase in ventricular muscle cells. J Biol Chem. 1998; 273:5423-6. [PubMed: 9488659]

Weismann CG, Gelb BD. The genetics of congenital heart disease: a review of recent developments. Curr Opin Cardiol. 2007; 22:200-6. [PubMed: 17413276]

Wilkie AO. Craniosynostosis: genes and mechanisms. Hum Mol Genet. 1997; 6:1647-56. [PubMed: 9300656]

Wu X, Simpson J, Hong JH, Kim KH, Thavarajah NK, Backx PH, Neel BG, Araki T. MEK-ERK pathway modulation ameliorates disease phenotypes in a mouse model of Noonan syndrome associated with the Raf1(L613V) mutation. J Clin Invest. 2011; 121:1009-25. [PubMed: 21339642]

Yamauchi K, Milarski KL, Saltiel AR, Pessin JE. Protein-tyrosine-phosphatase SHPTP2 is a required positive effector for insulin downstream signaling. Proceedings of the National Academy of Science of the United States of America. 1995; 92:664-668.

Yoshida R, Hasegawa T, Hasegawa Y, Nagai T, Kinoshita E, Tanaka Y, Kanegane H, Ohyama K, Onishi T, Hanew K, et al. Protein-tyrosine phosphatase, nonreceptor type 11 mutation analysis and clinical assessment in 45 patients with Noonan syndrome. J Clin Endocrinol Metab. 2004; 89:3359-64. [PubMed: 15240615]

Zhang D, Contu R, Latronico MV, Zhang J, Rizzi R, Catalucci D, Miyamoto S, Huang K, Ceci M, Gu $\mathrm{Y}$, et al. MTORC1 regulates cardiac function and myocyte survival through 4E-BP1 inhibition in mice. J Clin Invest. 2010; 120:2805-16. [PubMed: 20644257]

Zhang SQ, Tsiaras WG, Araki T, Wen G, Minichiello L, Klein R, Neel BG. Receptor-specific regulation of phosphatidylinositol 3'-kinase activation by the protein tyrosine phosphatase Shp2. Mol Cell Biol. 2002; 22:4062-72. [PubMed: 12024020]

Zhang SQ, et al. Shp2 regulates SRC family kinase activity and Ras/Erk activation by controlling Csk recruitment. Mol Cell. 2004; 13(3):341-55. [PubMed: 14967142] 


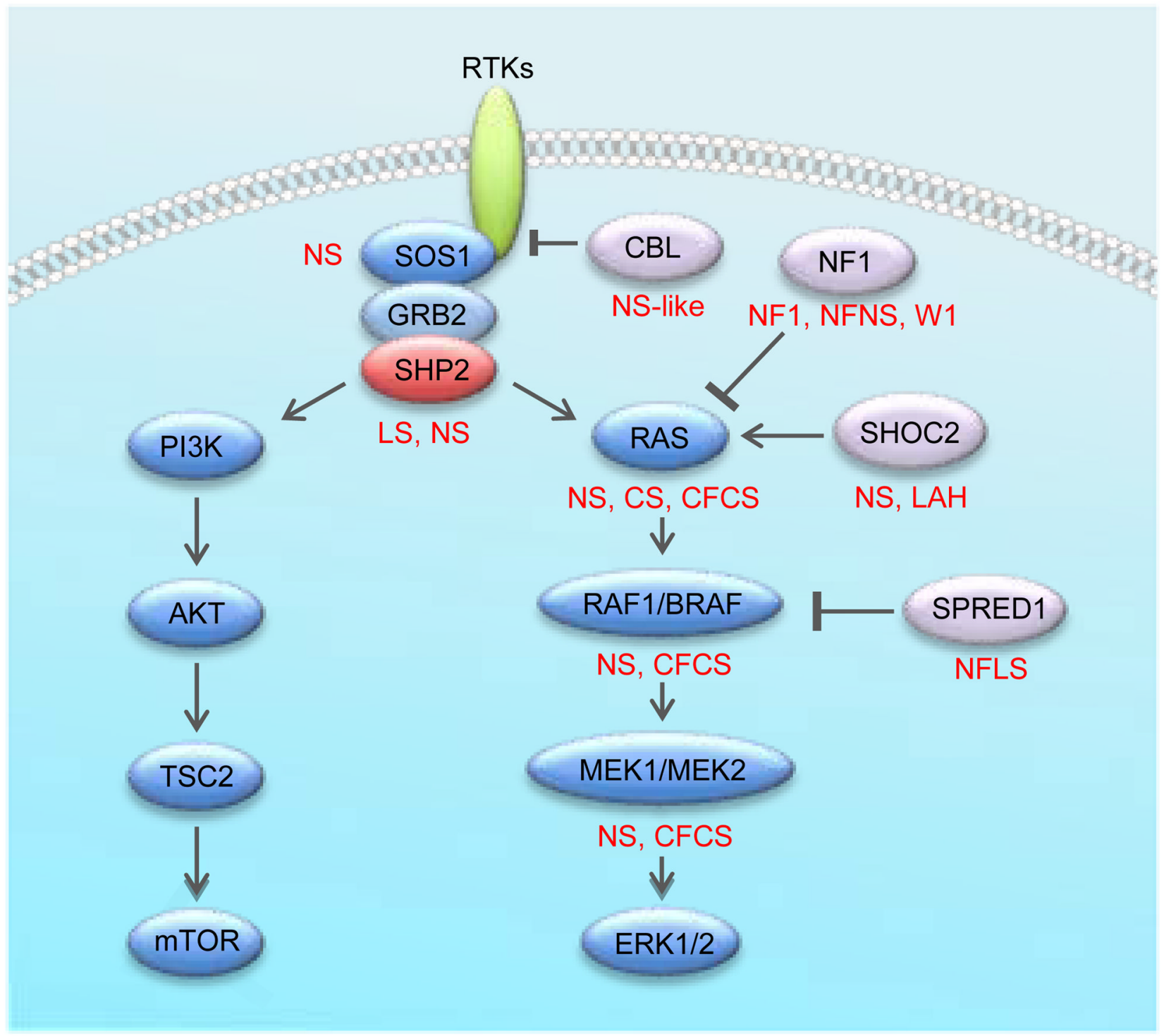

Figure 1. Depiction of the signal transduction pathway and individual genes affected in each RASopathy disorder

The Rasopathy disorder associated with each gene is indicated in red. Positive regulatory interactions are indicated with black arrows, and negative regulatory interactions are indicated with black blunted arrows. CFCS, Cardiofaciocutaneous Syndrome; CS, Costello Syndrome; LS, LEOPARD Syndrome, NF1, Neurofibromatosis type 1; NFLS, Neurofibromatosis type 1-Like Syndrome; NFNS, Neurofibromatosis-NS; NS, Noonan Syndrome; NS/LAH, Noonan-like Syndrome with Loose Anagen Hair; RTK, Receptor Tyrosine Kinase; WS, Watson Syndrome. 

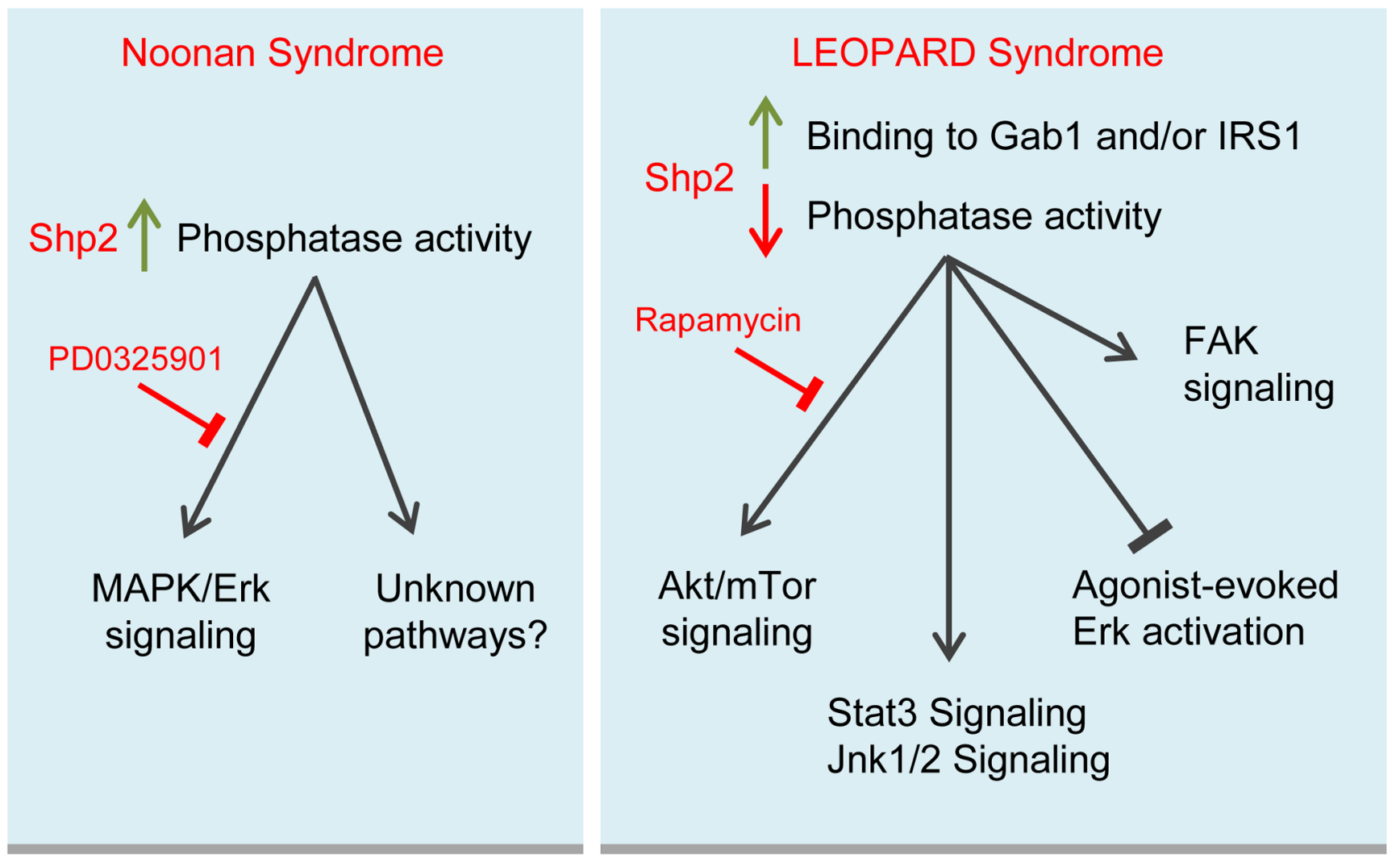

Figure 2. Signaling pathways aberrantly regulated in NS vs. LS, and their respective targeted therapies

While the two syndromes share common phenotypic characteristics, NS- and LS-associated SHP2 differ in their biochemical properties. NS mutations result in increased phosphatase activity and, therefore, increase MAPK signaling. In contrast, LS mutations are loss-offunction mutations that lead to impaired agonist-evoked ERK activation but have concomitantly induce activity in several other signaling pathways including Akt/mTor, FAK, Stat and Jnk. This strongly favors the use of targeted therapies (PD0325901 and Rapamycin) based on the biochemical properties of these disorders. Positive regulation is indicated with a grey arrow, whereas negative regulation is indicated with a blunted arrow. 
Table 1

\section{Cardiac defects associated with NS and LS}

NS and LS share common phenotypic characteristics, including several cardiac defects. However, the specific cardiac manifestations have a distinct distribution of frequency. While PTPN11 mutations in NS are more frequently associated with pulmonary stenosis, LS patients most frequently present with HCM.

\begin{tabular}{|c|c|c|}
\hline Syndrome & Cardiac defect & Frequency \\
\hline \multirow[b]{4}{*}{ Noonan ${ }^{1}$} & Pulmonary stenosis & $83 \%^{2}$ \\
\hline & Septal defects & $29 \%^{2}$ \\
\hline & Hypertrophic cardiomyopathy & $8 \%^{3}$ \\
\hline & $\begin{array}{l}\text { Valvular defects } \\
\text { Aortic coarctation } \\
\text { Mitral valve defects } \\
\text { Tetralogy of Fallot } \\
\text { Patent ductus arteriosus }\end{array}$ & Low frequency $(1-5 \%)$ \\
\hline \multirow{6}{*}{ LEOPARD $^{1}$} & $\begin{array}{l}\text { Hypertrophic cardiomyopathy } \\
\text { Left ventricular hypertrophy } \\
\text { Right ventricular hypertrophy }\end{array}$ & $\begin{array}{l}79-80 \% \\
73 \% \\
30 \%\end{array}$ \\
\hline & ECG anomalies & $73 \%$ \\
\hline & $\begin{array}{l}\text { Valvular defects } \\
\text { Mitral valve } \\
\text { Aortic valve }\end{array}$ & $\begin{array}{l}50 \% \\
42 \% \\
23 \%\end{array}$ \\
\hline & Pulmonary stenosis & $10-23 \%$ \\
\hline & Coronary abnormalities & $15 \%$ \\
\hline & Septal defects & Low frequency $(1-5 \%)$ \\
\hline
\end{tabular}

Defects are reported as:

${ }^{1}$ PTPN11 mutations,

2 cumulative incidence of 7 studies, and/or

3 cumulative incidence of 6 studies. Note: studies are inclusive of 341 NS and 57 LS patients (Limongelli et al. 2007; Sarkozy et al. 2004; Sznajer et al. 2007) 
Table 2

Amino acid substitutions caused by PTPN11 mutations in NS and LS and their resulting functional consequences

NS and LS have uniquely specific point mutations in PTPN11, each affecting the protein structure and/or enzymatic function of the PTP.

\begin{tabular}{|c|c|c|c|}
\hline Syndrome & Amino acid change & Site affected & Functional consequence \\
\hline \multirow{5}{*}{ Noonan } & D106A, E110A & $\begin{array}{l}\text { Linker stretch connecting the } \mathrm{N}-\mathrm{SH} 2 \\
\text { and } \mathrm{C}-\mathrm{SH} 2 \text { domains }\end{array}$ & $\begin{array}{l}\text { Presumed to alter the flexibility of the N-SH2 } \\
\text { domain, inhibit the N-SH2/PTP interaction and } \\
\text { increase phosphatase activity } 1,3\end{array}$ \\
\hline & T42A, E139D & $\begin{array}{l}\text { Involved in the interaction of the } \mathrm{SH} 2 \\
\text { domains with phosphotyrosyl- } \\
\text { containing peptides }\end{array}$ & $\begin{array}{l}\text { Increase affinity to phosphotyrosyl-containing } \\
\text { peptides and increase phosphatase activity } 1,2,3\end{array}$ \\
\hline & N308D, N308S, I309V & $\begin{array}{l}\text { In the PTP domain, make an } \\
\text { hydrogen bond with R501 }\end{array}$ & $\begin{array}{l}\text { Disrupt the hydrogen bond that may interact with } \\
\text { and stabilize the phosphate binding loop. Increase } \\
\text { phosphatase activity } 1,2,3\end{array}$ \\
\hline & $\begin{array}{l}\text { N58D, N58K, G60A, D61N, } \\
\text { D61G, Y62D, Y63C, E69Q, } \\
\text { F71L, A72S, A72G, T73I, } \\
\text { E76D, Q79P, Q79R, Q256R }\end{array}$ & $\begin{array}{l}\text { Involved in the interdomain (N-SH2/ } \\
\text { PTP) hydrogen bonding network } \\
\text { stabilizing the protein in the inactive } \\
\text { form }\end{array}$ & $\begin{array}{l}\text { Facilitate the opening of the structure and activation } \\
\text { of Shp2 and increase phosphatase activity } 1,2,3\end{array}$ \\
\hline & $\begin{array}{l}\text { T2I, I282V, F285L, F285S, } \\
\text { R501L, S502T, G503R, } \\
\text { M504V }\end{array}$ & $\begin{array}{l}\text { In close proximity to amino acids } \\
\text { participating in the stabilizing } \\
\text { network }\end{array}$ & $\begin{array}{l}\text { Facilitate opening of the structure and activation of } \\
\text { Shp2 and increase phosphatase activity } 1,2\end{array}$ \\
\hline \multirow{3}{*}{ LEOPARD } & Y279C & $\begin{array}{l}\text { Set the depth of the catalytic cleft in } \\
\text { the PTP active site and interact with } \\
\text { L70 and T62 in the N-SH2 domain }\end{array}$ & $\begin{array}{l}\text { Facilitate opening of the structure in the absence of } \\
\text { phosphatase activity } 1,2,3\end{array}$ \\
\hline & A461T, G464A, T468M & $\begin{array}{l}\text { Belong to the phosphatase signature } \\
\text { motif in the PTP active site }\end{array}$ & $\begin{array}{l}\text { Disrupt PTP loop resulting in absence of } \\
\text { phosphatase activity and displace the binding of } \\
\text { residues involved in the hydrogen bonding network, } \\
\text { facilitating opening of the structure } 1,3\end{array}$ \\
\hline & Q510P, Q510E & $\begin{array}{l}\text { Presumed to position water for } \\
\text { hydrolysis reaction in the PTP active } \\
\text { site }\end{array}$ & Absence of phosphatase activity 1,3 \\
\hline
\end{tabular}

Functional consequences for each of the reported mutations is based on:

1 structural analyses,

2 biochemical analyses, and/or

3 computer modeling (Darian et al. 2011; Hof et al. 1998; Keilhack et al. 2005; Kontaridis et al. 2006; Tartaglia and Gelb 2005) 